\title{
Antibacterial immunity to Vibrio cholerae in rats
}

\author{
G. N. COOPER AND R. NARENDRANATHAN
}

School of Microbiology, University of New South Wales, P.O. Box 1 Kensington 2033, New South Wales, Australia

Summary. Blind loops prepared in the small intestines of fasted, $\mathrm{MgSO}_{4}$-treated rats were shown to provide a simple, consistent and inexpensive means of studying mucosal colonisation by Vibrio cholerae serogroup $\mathrm{O} 1$. When $c .2000 \mathrm{cfu}$ were injected, the number of mucosa-associated $V$. cholerae in each loop increased by $c$. 5-6 orders of magnitude in 10-14 h, without enterotoxin-induced fluid production. Scanning electronmicroscopy and culture suggested that most surface-associated organisms were present in the adherent surface mucus. $V$. cholerae strains varied in terms of surface-colonising capacity.

Immunisation with $V$. cholerae given intra-intestinally greatly reduced the rate of increase and final number of mucosa-associated vibrios within the 14-h period after challenge. The method could be used to compare the immunity induced by various immunising regimens. Immunity was sometimes accompanied by intestinal mucusborne antibody against $V$. cholerae lipopolysaccharide but was sometimes demonstrated in the absence of such antibody or of mucus-borne antibody to heat-sensitive surface protein.

\section{Introduction}

Studies in volunteers support the notion that antibacterial mechanisms play a role in immunity to cholera (Levine et al., 1979). Antibody is presumed to interfere with the mucosal association of Vibrio cholerae. Cell wall lipopolysaccharide, outer-membrane proteins and other antigens have been implicated (Levine et al., 1983), but the important protective antigens have not yet been clearly defined. The identification of such antigens and the assessment of established and experimental vaccines require the use of in-vivo methods. $V$. cholerae infections in rabbit ileal loops (Freter, 1964), infant mice (Ujiiye and Kobari, 1970) and dogs (Curlin et al., 1970) have yielded a wealth of information on pathogenesis and immunity in cholera, but have not been used extensively in studies on actively induced antibacterial immunity (Cray et al., 1983). Recently, the "RITARD model" (Spira et al., 1981) and an alternative to it (Cray et al., 1983) have been used for studying cholera infection and immunity in adult rabbits. These models can be used to study live oral vaccines (Tokunaga et al., 1984) but are expensive and for this reason unsuitable for routine vaccine potency testing. Further, they have not yet been used to investigate the protective capacity of

Received 8 Oct. 1985; accepted 12 Nov. 1985. preparations that may be only weakly immunogenic when given orally.

Studies in this laboratory showed the rat to be a convenient animal for investigating local and systemic antibacterial antibody responses to intraintestinal injections of live $V$. cholerae (Cooper and Jackson, 1981; Jackson and Cooper, 1981; Cooper et al., 1984). It seemed of interest to determine whether these responses were related to immunity. It was first necessary, however, to discover whether the rat could be used to demonstrate active protection against $V$. cholerae infection. The present paper describes experiments designed to investigate this matter.

\section{Materials and methods}

\section{Bacterial strains}

The $V$. cholerae $\mathrm{O} 1$ strains used are described in table $\mathrm{I}$. They were preserved in the lyophilised state; stock cultures were maintained on Tryptose Soya Agar (TSA; Oxoid), subcultured each week and discarded after the third passage. Working cultures were grown in Tryptose Soya Broth (TSB; Oxoid) for $4 \mathrm{~h}$ at $37^{\circ} \mathrm{C}$ in a shaking waterbath. The organisms were harvested by centrifugation, resuspended in $0.1 \mathrm{M}$ phosphate-buffered saline (PBS; $p \mathrm{H} \mathrm{7.2)} \mathrm{and} \mathrm{diluted} \mathrm{in} \mathrm{PBS} \mathrm{to} \mathrm{the} \mathrm{required}$ concentration. Standard loop $(0.01 \mathrm{ml})$ dilution and plating on TSA were used to enumerate colony-forming units (cfu) in these suspensions (Schaedler et al., 1965). 


\section{Animals}

Adult Wistar strain rats of either sex were used; they were usually 60-90 days old.

\section{Immunisation}

For intra-intestinal (II) immunisation $c .10^{9} \mathrm{cfu}$ of $\mathrm{V}$. cholerae were injected in $1-\mathrm{ml}$ volumes of PBS into the jejunum (Robertson and Cooper. 1972). For intra-Peyer's patch (IPP; Cooper and Turner. 1967) immunisation. each of four patches in each animal received an injection of $25 \mu \mathrm{l}\left(10^{8}\right.$ organisms) of bacterial suspension. The organisms in the suspension were either alive. or killed by heat $(100 \mathrm{C} .2 \mathrm{~h})$ or by exposure to glutaraldehyde $0.2^{\circ}$ 。 for $2 \mathrm{~h}$.

\section{Antibody measurements}

Serum vibriocidal antibody titres were determined as described by Cooper and Jackson (1981). Lipopolysaccharide (LPS) and heat-sensitive surface protein (HSSP) antibodies to strain BRL 7738 in the three major immunoglobulin (Ig) classes were detected in intestinal mucus by solid phase ELISA. (Cooper et al., 1983). Antibody concentrations are expressed either as increases in titre above those found in normal mucus or as increases in $\mathrm{OD}_{\text {sos }} / 60 \mathrm{~min}$ values above normal (Cooper et al.. 1984).

\section{Intestinal loop infection in rats}

For $24 \mathrm{~h}$ animals were fasted and given a solution of $\mathrm{MgSO}_{4} \cdot 7 \mathrm{H}_{2} \mathrm{O} 10^{\circ}$ o instead of drinking water; water but not food was then restored for $4 \mathrm{~h}$. Laparotomy was performed through a mid-line incision under ether anaesthesia and three or four blind loops were constructed in the small intestine. silk thread being used for ligation. The distal loop was prepared $10 \mathrm{~cm}$ above the ileo-caecal junction; each loop was $5 \mathrm{~cm}$ long and separated from the next by $1 \mathrm{~cm}$. Each loop received $0.2 \mathrm{ml}$ of PBS containing 1000-8000 cfu of selected spontaneous streptomycinresistant $\left(\mathrm{S}^{r}\right)$ mutants of $V$. cholerae. In the first experiment (table I) 10 strains and a PBS control injection were compared, but in subsequent experiments an $\mathbf{S}^{r}$ mutant of the E1 Tor Inaba strain BRL7738 was used exclusively, except for the purpose of immunisation. The abdominal cavity was closed with silk sutures and Michel clips.

\section{Enumeration of $V$. cholerae in loops}

Lniess stated otherwise rats were killed by cervical dislocation under ether anaesthesia $14 \mathrm{~h}$ after inoculation. The loops were collected separately and, in some instances. their volumes determined by fluid displacement. Each loop was opened longitudinally and the mucoid luminal fluid drained off; the tissues were washed vigorously three times in $250 \mathrm{ml}$ of PBS to remove all material not firmly adherent to the mucosal surface. The tissuc of each loop was then homogenised in $10 \mathrm{ml}$ of PBS by means of a Teflon grinder; the number of mucosa- associated $V$. cholerae was then determined by diluting serially with a standard loop and plating on TSA containing streptomycin sulphate $100 \mu \mathrm{g} / \mathrm{ml}$. When no organisms were isolated from the loop tissue homogenates an arbitrary count of $1000 \mathrm{cfu}$ (the lower limit of detection by the counting technique) was assigned to permit calculation of means and standard deviations for each group.

On some occasions, the number of cfu in the luminal contents $\left(\mathrm{N}_{\mathrm{L}}\right)$ was determined from the formula: $\mathrm{N}_{\mathrm{L}}=\mathrm{N}$ $\left(L_{v}-0 \cdot 3\right)$, where $\mathbf{N}=$ count ( $\mathrm{cfu} / \mathrm{ml}$ ) of luminal fluid, and $\mathrm{L}_{\mathrm{v}}=$ displacement volume $(\mathrm{ml})$ of loop; $0.3 \mathrm{ml}$ was subtracted from the latter figure to account for the volume of the loop tissues, determined by preliminary experiments.

In one experiment, designed to distinguish between mucus-associated and epithelium-attached organisms, the washed loop tissues were placed in $1 \mathrm{ml}$ volumes of a solution containing $\mathrm{N}$-acetyl-L-cysteine (Sigma) $25 \mathrm{mg}$ in $0.05 \mathrm{~m}$ PBS adjusted to $\mathrm{pH} 7.0$ with $\mathrm{NaOH}$. The tissues were incubated at $37^{\circ} \mathrm{C}$ for $30 \mathrm{~min}$ to dissolve surfaceassociated mucus. The eluates were collected and the tissues washed in PBS before homogenising. Viable counts of the tissue homogenates and mucus eluates were then made. Preliminary experiments indicated that the viability of the infecting strain was not affected by the treatment, and the method of Kerss et al. (1982) was used to examine its effects on the adherent surface mucus of the intestinal loops.

\section{Microscopy}

Intestinal loops were opened and washed to remove luminal contents. For phase-contrast microscopy, mucus was gently scraped from the epithelial surface with the back of a scalpel blade; the scraping was then placed on a glass slide and "squashed" under a coverslip. For scanning electronmicroscopy the washed tissues were placed in fixative (glutaraldehyde $2.5 \%$ in $0.1 \mathrm{~m}$ sodium cacodylate at $p \mathrm{H} \mathrm{7.4)}$ for $4 \mathrm{~h}$. They were washed again and dehydrated through $50 \%, 75 \%, 90 \%$ and $100 \%$ ethanol, transferred to amyl acetate and dried by the critical point method in liquid $\mathrm{CO}_{2}$. Sections of tissues were mounted on aluminium stubs, sputter-coated with gold, and viewed in a Cambridge Stereoscan S4-10 microscope operated at $10 \mathrm{kV}$.

\section{Results}

Behaciour of 10 streptomycin-resistant mutants of $V$. cholerae in intestinal loops

The results in table I indicate that some fluid accumulated in all loops; however, when the means were compared by Student's $t$ test, the displacement volumes were similar $(p>0 \cdot 1)$ irrespective of whether the loops received injections of mouse virulent organisms, non-virulent organisms, or PBS. 
Table I. Behaviour of streptomycin-resistant mutants of $10 \mathrm{~V}$. cholerae strains in rat intestinal loops

\begin{tabular}{|c|c|c|c|c|c|c|}
\hline Strain & $\begin{array}{l}\text { Biotype/ } \\
\text { serotype* }\end{array}$ & $\begin{array}{c}\text { Infant mouse } \\
\text { virulence }\end{array}$ & Motility & $\begin{array}{l}\text { Mean loop } \\
\text { displacement } \\
\text { volume } \pm \text { SD } \\
\text { at } 14 \mathrm{~h} \ddagger(\mathrm{ml})\end{array}$ & $\begin{array}{l}\text { Mean increase } \\
\text { in inoculum } \\
\text { at } 14 \mathrm{~h} \|\end{array}$ & $\begin{array}{c}\text { Percentage organisms } \\
\text { associated } \\
\text { with mucosal } \\
\text { surfaces } \Phi\end{array}$ \\
\hline P388 & $\mathrm{E} / \mathrm{O}$ & + & + & $1 \cdot 70 \pm 0.47$ & $4.3 \times 10^{6}$ & $63 \cdot 9$ \\
\hline $\mathrm{O} 17$ & $\mathrm{E} / \mathrm{O}$ & + & + & $1.77 \pm 0.49$ & $2 \cdot 1 \times 10^{6}$ & $71 \cdot 9$ \\
\hline BRL7738 & $\mathrm{E} / \mathrm{I}$ & + & + & $1.61 \pm 0.95$ & $1.1 \times 10^{6}$ & $53 \cdot 3$ \\
\hline $\mathrm{O} 162$ & $\mathrm{C} / \mathrm{O}$ & - & + & $1 \cdot 20 \pm 0.48$ & $1.3 \times 10^{6}$ & $57 \cdot 0$ \\
\hline $111-V 58$ & $\mathrm{C} / \mathrm{O}$ & - & + & $1.28 \pm 0.38$ & $1.4 \times 10^{6}$ & $36 \cdot 0$ \\
\hline $35 \mathrm{~A} 3$ & $\mathrm{C} / \mathrm{I}$ & + & + & $1.69 \pm 0.69$ & $1.6 \times 10^{6}$ & $63 \cdot 4$ \\
\hline $569 B$ & $\mathrm{C} / \mathrm{I}$ & + & + & $1.56 \pm 0.46$ & $6.6 \times 10^{5}$ & $22 \cdot 1$ \\
\hline 111-V58NM & $\mathrm{C} / \mathrm{O}$ & - & - & $1 \cdot 19 \pm 0.42$ & $4.3 \times 10^{5}$ & 5.8 \\
\hline KB1 12 NM & $\mathrm{C} / \mathrm{O}$ & - & - & $1.60 \pm 0.49$ & $7.6 \times 10^{5}$ & $5 \cdot 6$ \\
\hline NW31 & $\mathrm{C} / \mathrm{R}$ & - & + & $1.39 \pm 0.44$ & $6.5 \times 10^{4}$ & $21 \cdot 1$ \\
\hline PBS control & $\ldots$ & $\ldots$ & $\ldots$ & $0.99 \pm 0.65$ & $\ldots$ & $\ldots$ \\
\hline
\end{tabular}

* $\mathrm{E}=\mathrm{E} 1$ Tor, $\mathrm{C}=$ Classical, $\mathrm{O}=$ Ogawa, $\mathrm{I}=$ Inaba, $\mathrm{R}=$ Rough.

$\dagger$ Determined as described by Attridge and Rowley (1983).

\$ Means determined from minimum of 16 loops in 4 rats.

$\left.\begin{array}{l}\| \text { From } \frac{N_{L}+N_{T}}{N_{c}} \\ \text { If From } \frac{N_{L}}{N_{L}+N_{T}}\end{array}\right\}$ where $N_{C}=c f u$ in challenge dose, $N_{L}=c f u$ in lumen contents,

As the inocula varied $(1000-8000 \mathrm{cfu})$, growth was compared in terms of the increase in numbers of cfu during the 14-h period. All strains grew in the loops and increased by $c$. 5-6 orders of magnitude. The results given in table I also suggest that strains differed in their capacity to associate with the mucosal surfaces; this capacity was least with the two non-motile strains tested, but did not appear to be related to virulence for infant mice.

\section{Location of mucosa-associated $V$. cholerae}

Rat intestinal loops received an injection of PBS or c. $2000 \mathrm{cfu}$ of strain BRL7738 $\left(\mathrm{S}^{\mathrm{r}}\right)$. Mucosal scrapings were examined $14 \mathrm{~h}$ later. Mucus from PBS-treated control loops contained fairly small numbers of a morphologically heterogeneous population of bacteria. In contrast, numerous commashaped organisms were present in mucus from $V$. cholerae-treated loops. In the fluid spaces these organisms showed the characteristic darting motility of $V$. cholerae, but the most striking feature was the large numbers of non-motile organisms aligned in rows along strands of mucin. On occasion, mucin-attached organisms were seen spinning rapidly like tops, suggesting attachment of their polar flagella.
Mucosal surfaces of loops samples 4,8 or $14 \mathrm{~h}$ after inoculation with $c .2000 \mathrm{cfu}$ were examined by scanning electronmicroscopy. As shown in fig. 1, after $4 \mathrm{~h}$ few comma-shaped organisms were seen in the mucin network overlying the epithelium and none attached to the epithelium. The number of organisms apparently in contact with the surfaces of the intestine increased during the following $10 \mathrm{~h}$, but most organisms present 8 and $14 \mathrm{~h}$ after injection were associated with the overlying mucus.

\section{Mucus-associated and epithelium-attached orga- nisms}

Strain BRL7738 ( $\mathbf{S}^{\mathrm{r}}$; c. $\left.2000 \mathrm{cfu}\right)$ was injected into intestinal loops. The loops were taken 2, 4, 6, 8 and $14 \mathrm{~h}$ later and, after washing, the mucosal surfaces were exposed to the mucolytic agent $\mathrm{N}$-acetyl-Lcysteine to remove the adherent blanket of mucus; microscopical examination (Kerss et al., 1982) confirmed that virtually all of it was removed after treatment for $30 \mathrm{~min}$. Viable counts of the mucus eluates and treated tissue homogenates were compared. Throughout the $14-\mathrm{h}$ period more than $75 \%$ of the mucosa-associated organisms appeared to be located in material that was readily dislodged by the mucolytic agent (table II). 


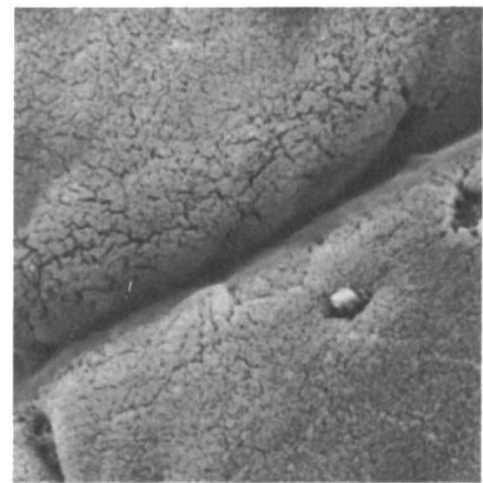

A

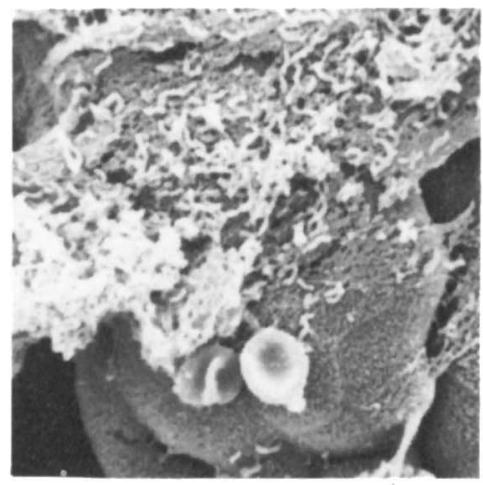

C

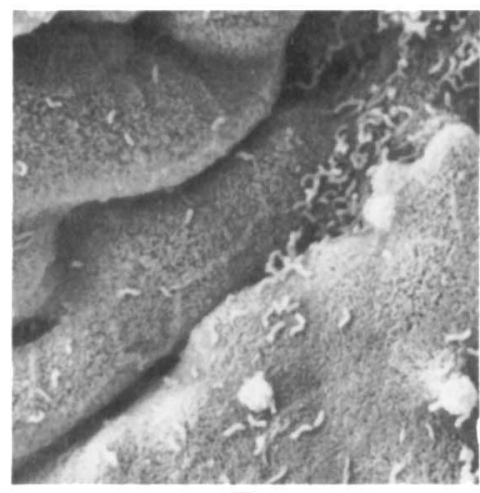

E

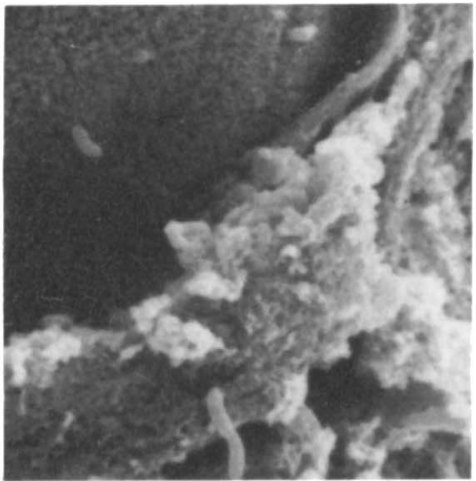

B

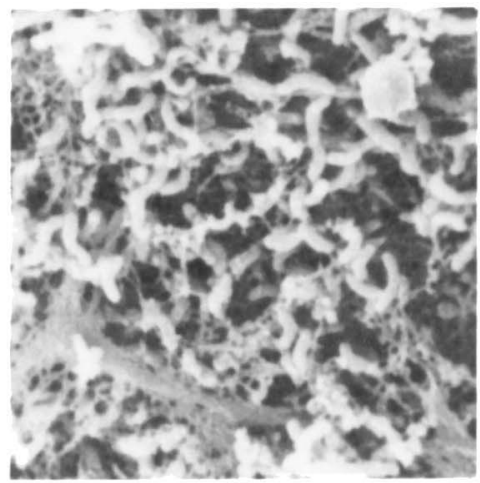

D

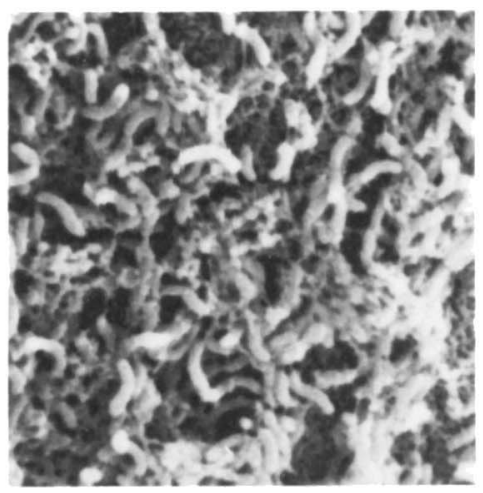

$\mathrm{F}$

Fig. 1. Scanning electronmicrographs of rat intestinal-loop surfaces taken $4 \mathrm{~h}(\mathrm{~A}, \mathrm{~B}) 8 \mathrm{~h}(\mathrm{C}, \mathrm{D})$ and $14 \mathrm{~h}(\mathrm{E}, \mathrm{F})$ after inoculation with $200 \mathrm{cfu}$ of $V$. cholerae BRL7738 $\left(\mathrm{S}^{\mathrm{r}}\right)$. A, C, E (magnification $c . \times 8000$ ) show the villus epithelial surfaces; B, D, E (magnification $c$. $\times 24000)$ were randomly selected areas in which part of the adherent mucus blanket was retained.

Local immunisation and association of organisms with the mucosa

LPS and HSSP antibodies to strain BRL7738 appeared in rat intestinal mucus some days after the second of two II injections of live 569B organisms given 14 days apart (fig. 2); in each instance, the organisms disappeared from the intestine within $2448 \mathrm{~h}$ of injection (Cooper and Jackson, 1981). Accordingly, this immunising regimen was used in an experiment to compare the growth of mucosaassociated organisms in loops of normal and immunised rats. In both instances, doses of $c .2000 \mathrm{cfu}$ of the challenge strain were used and immunised 
Table II. Recovery of $V$. cholerae BRL7738 from mucus and epithelial surfaces of rat intestinal loops

\begin{tabular}{|c|c|c|c|}
\hline \multirow{2}{*}{$\begin{array}{l}\text { Time after } \\
\text { injection of } \\
\text { organisms } \\
\text { (h) }\end{array}$} & \multicolumn{2}{|c|}{$\begin{array}{c}\text { Mean log no. of organisms } \pm \mathrm{SD}^{*} \\
\text { from }\end{array}$} & \multirow{2}{*}{$\begin{array}{l}\text { Percentage of mucosa- } \\
\text { associated organisms } \\
\text { in mucus eluates }\end{array}$} \\
\hline & mucus eluates $\dagger$ & tissue homogenates + & \\
\hline 2 & $3 \cdot 19 \pm 1 \cdot 41$ & $<3.00$ & ND \\
\hline 4 & $4.83 \pm 0.55$ & $4.01 \pm 0.59$ & $85 \cdot 2$ \\
\hline 6 & $6 \cdot 27 \pm 0.59$ & $5.31 \pm 0.72$ & $90 \cdot 1$ \\
\hline 8 & $7 \cdot 18 \pm 0.57$ & $6.32 \pm 0.55$ & 87.9 \\
\hline 14 & $8.45 \pm 0.53$ & $7.92 \pm 0.93$ & $77 \cdot 1$ \\
\hline
\end{tabular}

* From 16 individual loops at each time.

† Obtained by treatment with $\mathrm{N}$-acetyl-L-cysteine.

$\ddagger$ After treatment with $\mathrm{N}$-acetyl-L-cysteine.

$\mathrm{ND}=$ not determined.

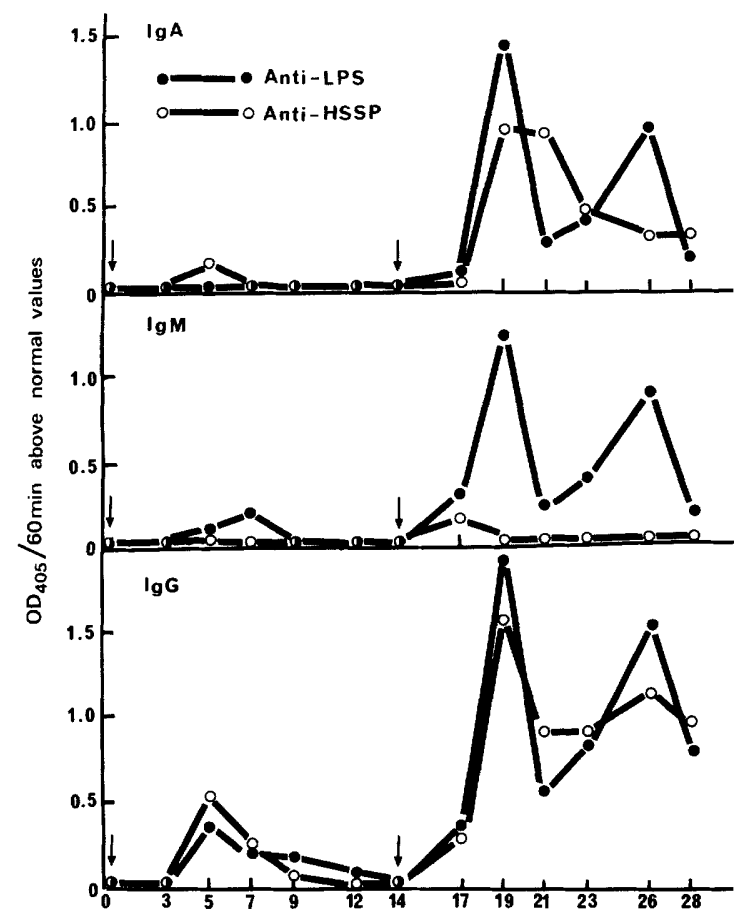

Time after injection (days)

Fig. 2. Antibody production in adherent intestinal mucus of rats following II doses of $10^{9} \mathrm{cfu}$ of $V$. cholerae 569B given on days 0 and 14. ELISA was used to detect antibodies in the three major immunoglobulin classes.

animals were challenged 5 days after the second immunising dose, i.e., at the peak of the mucus antibody responses. Fig. 3 indicates that in the loops of normal rats mucosa-associated organisms

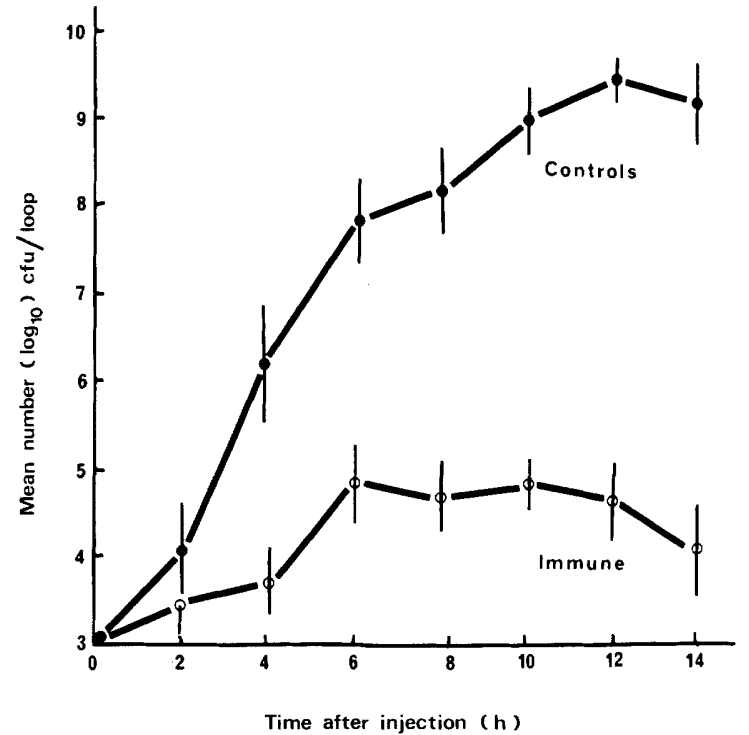

Fig. 3. Behaviour of mucosa-associated $V$. cholerae BRL7738(Sr) organisms in intestinal loops of control and immunised rats; the latter were challenged 5 days after the second of two II immunising doses of $V$. cholerae 569B given 14 days apart.

increased exponentially for $c .10 \mathrm{~h}$ and maximum numbers were maintained over a further $2-4 \mathrm{~h}$ period. Numbers recovered from normal and immunised rat loop surfaces $2 \mathrm{~h}$ after challenge did not differ significantly ( $\mathrm{p}>0 \cdot 2$ by Student's $t$ test), but subsequently bacterial multiplication was much less in immune than in control animals. After 10-14 $h$, the differences in mean numbers of mucosaassociated organisms found in the two groups were approximately 100000 -fold. 


\section{Efficacy of different immunising regimens}

First, groups of eight rats were given two II or IPP doses of live organisms of the classical biotype strains 569B (Inaba), Ol62 (Ogawa), or NW31 (a rough mutant of O162). The injections were separated by 14 days and the intestinal loops were challenged with strain BRL7738 5 days after the second dose. Matched groups of normal animals were included and mucosa-associated organisms were enumerated after $14 \mathrm{~h}$. Similar groups were used to determine intestinal mucus antibody concentrations induced by the immunising regimens. The results summarised in tables III and IV demonstrate that strain 569B was strongly immunogenic and protected against mucosal colonisation when

Table III. Effect of local immunisation with live $V$. cholerae on mucosal colonisation in rat intestinal loops by strain BRL7738

\begin{tabular}{|c|c|c|c|c|}
\hline \multirow[b]{2}{*}{$\begin{array}{l}\text { Immunising } \\
\text { strain }\end{array}$} & \multirow[b]{2}{*}{$\begin{array}{l}\text { Immunising } \\
\text { route }\end{array}$} & \multicolumn{2}{|c|}{$\begin{array}{l}\text { Mean } \log _{10} \text { no. of } \\
\text { organisms } \pm \mathrm{SD}^{*} \\
\text { recovered from }\end{array}$} & \multirow{2}{*}{$\begin{array}{l}\text { Difference in } \log _{10} \text { units } \\
\text { between mean results in control } \\
\text { and immunised loops ( } \mathrm{p} \text { values } t \text { ) }\end{array}$} \\
\hline & & $\begin{array}{l}\text { control } \\
\text { loops }\end{array}$ & $\begin{array}{l}\text { immunised } \\
\text { loops }\end{array}$ & \\
\hline \multirow[t]{2}{*}{$569 \mathrm{~B}$} & II & $9 \cdot 69 \pm 0 \cdot 17$ & $4.83 \pm 0.72$ & $4.86(<0.01)$ \\
\hline & IPP & $9 \cdot 26 \pm 0.20$ & $4.97 \pm 0.97$ & $4.29(<0.01)$ \\
\hline \multirow[t]{2}{*}{0162} & II & $10 \cdot 23 \pm 0.06$ & $8 \cdot 22 \pm 1 \cdot 77$ & $2.01 \quad(<0.05)$ \\
\hline & IPP & $9.39 \pm 0.60$ & $4.39 \pm 0.95$ & $5.00(<0.01)$ \\
\hline \multirow[t]{2}{*}{ NW31+ } & II & $10 \cdot 16 \pm 0.09$ & $9.93 \pm 0.38$ & $0.23(>0.90)$ \\
\hline & IPP & $9.82 \pm 0.27$ & $9.72 \pm 0.23$ & $0.10(>0.90)$ \\
\hline
\end{tabular}

II = intra-intestinal; IPP = intra-Peyer's patch.

Two doses of $10^{9} \mathrm{cfu}$ separated by 14 days given by the II route, and two of $4 \times 10^{8} \mathrm{cfu}$ by the IPP route.

* Immunised rats challenged 5 days after second immunising dose; means determined from 24 loops prepared in eight rats.

+ Values of $p$ determined by comparison of means with Student's $t$ test.

† rough variant of strain 0162 .

Table IV. $V$. cholerae antibodies in serum and intestinal surface mucus of rats immunised with live $V$, cholerae strains

\begin{tabular}{|c|c|c|c|c|c|c|c|c|}
\hline \multirow{3}{*}{$\begin{array}{l}\text { Immunising } \\
\text { strain }\end{array}$} & \multirow{3}{*}{$\begin{array}{l}\text { Immunising } \\
\text { route }\end{array}$} & \multirow{3}{*}{$\begin{array}{c}\text { Mean } \\
\text { serum vibriocidal } \\
\text { antibody titre }\end{array}$} & \multicolumn{6}{|c|}{$\begin{array}{c}\text { Mean ELISA antibody concentra } \\
\text { tions* in mucus }\end{array}$} \\
\hline & & & \multicolumn{3}{|c|}{ Anti-LPS } & \multicolumn{3}{|c|}{ Anti-HSSP } \\
\hline & & & $\operatorname{Ig} A$ & $\operatorname{IgM}$ & IgG & $\operatorname{Ig} A$ & IgM & IgG \\
\hline \multirow[t]{2}{*}{$569 \mathrm{~B}$} & II & $1.5 \times 10^{6}$ & 16.9 & $21 \cdot 6$ & $23 \cdot 3$ & 8.9 & 0 & $21 \cdot 8$ \\
\hline & IPP & $1.2 \times 10^{6}$ & $5 \cdot 1$ & 28.9 & $18 \cdot 2$ & $4 \cdot 5$ & $10 \cdot 2$ & $9 \cdot 7$ \\
\hline \multirow[t]{2}{*}{0162} & II & $1.4 \times 10^{5}$ & 0 & $7 \cdot 2$ & 0 & 0 & 0 & 0 \\
\hline & IPP & $6.4 \times 10^{5}$ & 0 & 0 & $6 \cdot 3$ & 0 & 0 & 0 \\
\hline \multirow[t]{2}{*}{ NW31+ } & II & $<1 \times 10^{\prime}$ & 0 & 0 & 0 & 0 & 6.7 & $8 \cdot 1$ \\
\hline & IPP & $<1 \times 10^{1}$ & 0 & 0 & 0 & $4 \cdot 8$ & $10 \cdot 2$ & $15 \cdot 5$ \\
\hline
\end{tabular}

Values determined 5 days after the second of two immunising doses separated by 14 days; eight rats used in each group.

II = intra-intestinal: IPP = intra-Peyer's patch.

* Expressed as increases in titre above those of normal rat intestinal mucus; increases of $<4$ are not significant and are shown as 0 .

+ A rough variant of strain 0162 . 
Table V. Antibody responses and immunity to mucosal colonisation by strain BRL7738 after IPP immunisation with live and killed $V$. cholerae $569 \mathrm{~B}$ vaccines

\begin{tabular}{|c|c|c|c|c|c|c|c|c|}
\hline \multirow{3}{*}{$\begin{array}{l}\text { Immunising } \\
\text { antigen }\end{array}$} & \multirow{3}{*}{$\begin{array}{c}\text { Number of } \\
\text { doses }\end{array}$} & \multirow{3}{*}{$\begin{array}{l}\text { Days after last } \\
\text { injection }\end{array}$} & \multirow{3}{*}{$\begin{array}{l}\text { Mean serum } \\
\text { vibriocidal } \\
\text { antibody } \\
\text { titre }\end{array}$} & \multicolumn{4}{|c|}{$\begin{array}{l}\text { Mean ELISA } \\
\text { antibody } \\
\text { concentrations } * \dagger \\
\text { in mucus }\end{array}$} & \multirow{3}{*}{$\begin{array}{l}\text { Difference ( } \log _{10} \text { units) } \\
\text { between mean numbers of } \\
\text { organisms in control and } \\
\text { immunised loops } \ddagger\end{array}$} \\
\hline & & & & \multicolumn{2}{|c|}{ Anti-LPS } & \multicolumn{2}{|c|}{ Anti-HSSP } & \\
\hline & & & & $\overline{I g A}$ & IgG & $\operatorname{Ig} \mathrm{A}$ & IgG & \\
\hline \multirow{5}{*}{ Live organisms } & 1 & 5 & $3.2 \times 10^{4}$ & 0 & 0 & 0 & 0 & $2 \cdot 00$ (NS) \\
\hline & & 14 & $3.2 \times 10^{4}$ & 0 & 0 & 0 & $4 \cdot 7$ & $2.45(\mathrm{~S})$ \\
\hline & $2 \|$ & 5 & $1.3 \times 10^{6}$ & $5 \cdot 1$ & 28.9 & $4 \cdot 5$ & $9 \cdot 7$ & $4.29(\mathrm{~S})$ \\
\hline & & 14 & $3.2 \times 10^{5}$ & - & $20 \cdot 2$ & - & $5 \cdot 3$ & $5 \cdot 26(\mathrm{~S})$ \\
\hline & & 42 & $3.2 \times 10^{3}$ & - & 4.5 & - & - & $4 \cdot 13(\mathrm{~S})$ \\
\hline \multirow{5}{*}{$\begin{array}{l}\text { Heat-killed } \\
\text { organisms }\end{array}$} & 1 & 5 & $2 \cdot 3 \times 10^{3}$ & 0 & 0 & 0 & 0 & $1.83(\mathrm{NS})$ \\
\hline & & 14 & $8 \times 10^{2}$ & 0 & 0 & 0 & 0 & 1.44 (NS) \\
\hline & $2 \|$ & 5 & $1.6 \times 10^{5}$ & 0 & $6 \cdot 7$ & 0 & 0 & 4.09 (S) \\
\hline & & 14 & $8 \times 10^{2}$ & 0 & $6 \cdot 2$ & 0 & 0 & 4.05 (S) \\
\hline & & 42 & $<1 \times 10^{1}$ & 0 & 0 & 0 & 0 & 1.39 (NS) \\
\hline \multirow{5}{*}{$\begin{array}{l}\text { Glutaraldehyde- } \\
\text { killed } \\
\text { organisms }\end{array}$} & 1 & 5 & $4 \times 10^{3}$ & 0 & 0 & 0 & 0 & $1 \cdot 18$ (NS) \\
\hline & & 14 & $6.4 \times 10^{4}$ & 0 & 0 & 0 & 0 & 3.37 (S) \\
\hline & $2 \|$ & 5 & $1.5 \times 10^{6}$ & $8 \cdot 8$ & $14 \cdot 5$ & 0 & $8 \cdot 5$ & $4.85(\mathrm{~S})$ \\
\hline & & 14 & $1.2 \times 10^{5}$ & 0 & $7 \cdot 4$ & 0 & 0 & $4.36(\mathrm{~S})$ \\
\hline & & 42 & $1.3 \times 10^{3}$ & 0 & 0 & 0 & 0 & $4 \cdot 39$ (S) \\
\hline
\end{tabular}

\footnotetext{
* Determined in groups of eight animals at each time.

$\dagger$ Expressed as in table IV.

$\ddagger$ Determined as in table III.

II Doses spaced by 14 days.

$\mathrm{S}=$ significant at $1 \%$ level of Student's $t$ test.
}

given by either route. In contrast, the rough strain NW31 given by either route failed to protect, even though significant antibody responses to the HSSP antigens of the challenge strain were found in mucus at the time of challenge; strain NW31 did not evoke LPS or vibriocidal antibody responses. Though the smooth parent of NW31 (O162) elicited Inaba LPS antibody, the responses were lower than in 569Bimmunised rats; they were confined to the IgM or IgG classes, depending on the route of immunisation. Strain O162 did not elicit significant increases of HSSP antibody in mucus. Curiously, although it was poorly protective when given intra-intestinally, by IPP injection it gave an immunity apparently as strong as that induced by strain 569B.

In a further experiment the IPP immunisation route was used to compare live 569B organisms and those killed by heat or glutaraldehyde, in terms of their ability to stimulate antibody production and resistance. The IPP route was used because preliminary experiments had indicated that by the II route two doses of the killed vaccines were not immunogenic. Animals were challenged, along with matched control groups, at various times after one or two doses of the vaccines; similarly immunised groups were used to determine serum vibriocidal antibody titres and antibody output in intestinal mucus. The results in table $\mathrm{V}$ indicate that all three vaccines gave rise to vibriocidal antibodies in serum during the primary response. However, no LPS antibodies were found in intestinal mucus following a single dose of any preparation, but with live organisms a significant increase in HSSP antibodies was recorded on day 14. Secondary vibriocidalantibody responses in serum were highest in rats immunised with live or glutaraldehyde-killed organisms and were still present 6 weeks after the second injection; those induced by the heat-killed organisms were shorter lived. Live organisms were more immunogenic than the killed vaccines in terms of inducing and maintaining LPS and HSSP antibodies in mucus. A single dose of live or glutaraldehyde-killed organisms-but not those killed by heat-stimulated some protection against mucosal colonisation 5-14 days after injection. All three vaccines were strongly protective after two doses; immunity to colonisation developed within 5 days of the second dose but persisted for at least 6 weeks 
only in rats immunised with live or glutaraldehydekilled organisms.

\section{Discussion}

Recent studies suggest that fluid accumulation in rat jejunal loops inoculated with purified toxin (CT) provides a good model of enterotoxin-induced diarrhoea (Lange, 1982) and may be used to investigate antitoxic immunity to cholera (Lange et al. 1984). However. for studies on antibacterial immunity, a model that reflects the organism's capacity to colonise intestinal mucosa may be more appropriate. Though the rabbit ileal loop has been used for this purpose (Freter, 1969) the potential advantages of rats over other laboratory animals (Lange. 1982) encouraged the present studies. Spontaneous fluid secretion, haemorrhage and gangrene. encountered with rat ileal loops by Lange (1982). were largely prevented by ensuring that the loops were well-vascularised and freed of luminal contents by prior fasting and $\mathrm{MgSO}_{4}$ treatment. Results obtained from loops showing punctate haemorrhages or gangrene were discarded, and the complication of CT-induced secretion was avoided by examining the loops within $14 \mathrm{~h}$ of infection.

$V$. cholerae grew rapidly in rat ileal loops and large numbers of organisms were found on the mucosal surfaces. As with other models (Yancey et al.. 1978: Attridge and Rowley, 1983) the rat method revealed variation between strains in their ability to colonise the mucosa, a property strikingly associated with motility. With the best colonisers, more than $50^{\circ}$ of organisms in the loops were firmly associated with the mucosal surfaces. In loops of normal animals. mucosa-associated organisms increased exponentially for $c .10 \mathrm{~h}$ and maximum numbers were reached within $14 \mathrm{~h}$ of infection. However, in rats first immunised by two spaced intestinal doses of live organisms of strain 569B. little increase occurred. It proved possible to compare various immunising regimens, and the IPP route of inoculation was useful for comparing vaccines that were too weakly immunogenic to be given by the II route.

Protection was not biotype or serotype specific, and the heat resistance of the protective antigens and their absence from a rough strain suggested

\section{REFERENCES}

Attridge S R. Rowley D 1983 The role of the flagellum in the adherence of Vibrio cholerae. Journal of Infectious Diseases 147:864-872, their LPS nature. The protective activity of LPS has been established by others (e.g., Holmgren and Svennerholm, 1983) and the immunity observed in animals inoculated with the heterologous (Ogawa) serotype was most likely due to serological crossreactivity between the Inaba and Ogawa LPS antigens. On current evidence, immunity attributable to the LPS antigens appears to exist only while LPS antibody is detectable in the intestinal mucus by ELISA.

The rough strain NW31 stimulated production of HSSP antibodies in intestinal mucus but did not protect. The serologically common $(40-44) \times 10^{3}$ mol. wt outer-membrane proteins of $V$. cholerae (Cooper et al., 1983) are therefore unlikely to be concerned in antibacterial immunity. Nonetheless, comparison of the protective capacities of heat-and glutaraldehyde-killed whole organisms suggested that other heat-sensitive antigens may be protective. This was revealed only when LPS antibodies induced by the two vaccines were no longer detectable in intestinal mucus, i.e., 42 days after the second immunising dose. At this time rats given the glutaraldehyde-killed organisms were strongly resistant. Although most unlikely, a rapid response (i.e., within $2 \mathrm{~h}$ ) to LPS antigen in the challenge inoculum cannot be excluded as the mechanism of immunity in this instance. Alternatively it must be accepted that protective antibodies, if present in the mucus. cannot as yet be identified by serological means.

During the secondary responses to all the immunising materials used in this study, immunity to colonisation was found only in animals possessing serum vibriocidal antibodies at the time of challenge. The relation between these antibodies and immunity to cholera in man has been discussed previously (e.g., Mosley et al., 1968). The results of the present study suggest that the rat model may provide a means of investigating the nature of antibacterial immunity to cholera.

This work was supported by grants from the World Health Organization's Diarrhoeal Diseases Control Programme and the National Health and Medical Research Council of Australia. The assistance of Ms Janet Sharp and the contribution of Dr M. R. Dickson, Biomedical Electron Microscope Unit, University of New South Wales, is greatly appreciated.
Cooper G N. Jackson G D F 1981 Immune responses of rats to live Vibrio cholerae: antibodies in serum and intestinal secretions. Parasite Immunology 3:57-68.

Cooper G N, McNab C E, Jackson G D F, Walker P 1983 Enzyme-linked immunoassays for antibodies against Vibrio 
cholerae. Australian Journal of Experimental Biology and Medical Science 61:713-725.

Cooper G N, McNab C E, Walker P G, Jackson G D F 1984 Intestinal antibodies in rats following exposure to live Vibrio cholerae. Australian Journal of Experimental Biology and Medical Science 62:465-477.

Cooper G N, Turner K 1967 Immunological responses in rats following antigenic stimulation of Peyer's patches. 1. Characteristics of the primary response. Australian Journal of Experimental Biology and Medical Science 45:363-378.

Cray W C, Tokunaga E, Pierce N F 1983 Successful colonization and immunization of adult rabbits by oral inoculation with Vibrio cholerae O1. Infection and Immunity 41:735-741.

Curlin G T, Craig J P, Subong A, Carpenter C C J 1970 Antitoxic immunity in experimental canine cholera. Journal of Infectious Diseases 121:463-470.

Freter R 1964 Comparison of immune mechanisms in various experimental models of cholera. Bulletin of the World Health Organization 31:825-834.

Freter R 1969 Studies of the mechanism of action of intestinal antibody in experimental cholera. Texas Reports of Biology and Medicine 27 (Suppl 1):299-316.

Holmgren J, Svennerholm A M 1983 Cholera and the immune response. Progress in Allergy 33:106-119.

Jackson G D F, Cooper G N 1981 Immune responses of rats to live Vibrio cholerae: secretion of antibodies in bile. Parasite Immunology 3:127-135.

Kerss S, Allen A, Garner A 1982 A simple method for measuring thickness of the mucus gel layer adherent to rat, frog and human gastric mucosa; influence of feeding, prostaglandin, $\mathrm{N}$-acetylcysteine and other agents. Clinical Science (London) 63:187-195.

Lange S 1982 A rat model for an in vivo assay of enterotoxic diarrhea. FEMS Microbiology Letters 15:239-242.

Lange S, Lonnroth I, Nygren H 1984 Protection against experimental cholera in the rat: A study on the formation of antibodies against cholera toxin and desensitization of adenylate cyclase after immunization with cholera toxin.
International Archives of Allergy and Applied Immunology 75:143-149.

Levine M M, Kaper J B, Black R E, Clements M L 1983 New knowledge on pathogenesis of bacterial enteric infections as applied to vaccine development. Microbiological Reviews 47:510-550.

Levine M M, Nalin D R, Craig J P, Hoover D, Bergquist E J, Waterman D, Holley H P, Hornick R B, Pierce N F, Libonati J P 1979 Immunity of cholera in man: relative role of antibacterial versus antitoxic immunity Transactions of the Society of Tropical Medicine and Hygiene 73:3-9.

Mosley W H, Benenson A S, Barui R 1968 A serological survey for cholera antibodies in rural East Pakistan. I. The distribution of antibody in the control population of a cholera-vaccine field-trial area and the relation of antibody titre to the pattern of endemic cholera. Bulletin of the World Health Organization 38:327-334.

Robertson P W, Cooper G N 1972 Immune responses in intestinal tissues to particulate antigens. Plaque-forming and rosette-forming cell responses in rats. Australian Journal Experimental Biology and Medical Science 50:703-714.

Schaedler R W, Dubos R, Costello R 1965 The development of the bacterial flora in the gastrointestinal tract of mice. Journal of Experimental Medicine 122:59-66.

Spira W M, Sack R B, Froehlich J L 1981 Simple adult rabbit model for Vibrio cholerae and enterotoxigenic Escherichia coli diarrhea. Infection and Immunity 32:739-747.

Tokunaga E, Cray W C, Pierce N F 1984 Compared colonizing and immunizing efficiency of toxinogenic $\left(\mathrm{A}^{+} \mathrm{B}^{+}\right)$Vibrio cholerae and an $\mathrm{A}^{-} \mathrm{B}^{+}$mutant (Texas Star-SR) studied in adult rabbits. Infection and Immunity 44:364-369.

Ujiiye A, Kobari K 1970 Protective effect on infections with Vibrio cholerae in suckling mice caused by the passive immunization with milk of immune mothers. Journal of Infectious Diseases 121 (Suppl.):S50-S55.

Yancey R J, Willis D L, Berry L J 1978 Role of motility in experimental cholera in adult rabbits. Infection and Immunity 22:387-392. 